\title{
Understanding the Significance \& Complexity of the Brady Rule
}

\author{
Prisha Mehta ${ }^{1}$ and Ryne Sandel ${ }^{\#}$ \\ ${ }^{1}$ Centennial High School, Frisco, TX, USA \\ \#Advisor
}

\section{$\underline{\text { ABSTRACT }}$}

My independent study final product is a means of demonstrating the importance and complexity of evidentiary disclosure in the American criminal justice system. To accomplish this, I designed an experiment to evaluate the impact of Brady violations on the outcome of a criminal trial or plea negotiation. The experiment involved presenting two different versions of a fictional criminal case to forty-four volunteer participants, who were randomly organized into two even groups: Group A and Group B. Version A of the case included the totality of the evidence collected during the discovery phase of the case while Version B of the case omitted a single piece of "exculpatory" evidence to produce the effect of a Brady violation. After reading the given facts, participants in both groups A and B were asked to answer questions regarding the defendant's culpability and the wisest course of legal action. Participants were given a specified period between three weeks and three days to review the facts and submit their answers to the experimental questions. The results of this experiment and my supporting research on federal and state disclosure regimes show that the "materiality" clause in the Brady Rule subjects prosecutors to highly subjective and vague criteria that 1) can easily be exploited by prosecutors with malicious intents and 2) increase the risk of unintended Brady violations by good-meaning prosecutors.

\section{Introduction}

With its decision in Brady v. Maryland, the Supreme Court established the disclosure duty and declared that "the suppression of evidence favorable to an accused upon request violates due process where evidence is material to either guilt or punishment, irrespective of the good or bad faith of the prosecution". ${ }^{1}$ This landmark decision birthed what is now widely known as the Brady rule, which requires prosecutors to disclose all materially exculpatory evidence, or Brady material, to the defense. The disclosure requirement established by Brady v. Maryland, for the first time in our nation's history, challenged traditional common law principles of discovery, which for centuries had offered defendants little protection from unscrupulous and negligent prosecutors.

In the decades following the creation of the initial Brady doctrine, a series of Supreme Court decisions revised, clarified, and expanded on some of its terms. Most notably in United States v. Giglio and United States v. Bagley, the court expanded on its definition of favorable evidence, affirming that favorable evidence includes not only exculpatory evidence but witness impeachment evidence as well. ${ }^{2}$ Furthermore, the Court clarified that a defense attorney need not request Brady evidence for it to be appropriately disclosed but that prosecutors must take it upon themselves to disclose Brady evidence, regardless of whether the defense requests it. ${ }^{3}$ At the same time, the Court also

${ }^{1}$ See Brady v. Maryland 373 U.S. 83, 87 (1963).

${ }^{2}$ See United States v. Bagley, 473 U.S. 667, 676 (1985); Giglio v. United States, 405 U.S. 150, 154-55 (1972).

${ }^{3}$ See United States v. Bagley, 473 U.S. 667, 676 (1985); United States v. Agurs, 427 U.S. 97, 112-13 (1976); Giglio

v. United States, 405 U.S. 150, 153-55 (1972); Harm v. State, 183 S.W.3 d 4o3, 4 o6 (Tex. Crim. App. 2oo6). 
limited Brady's scope with its holding in United States v. Bagley, ruling that a constitutional violation only occurs if there is a reasonable probability that the outcome of the trial would have been different. ${ }^{4}$

The federal and state court systems differ in their application of the Brady doctrine. Disclosure requirements in individual states are diverse due to local statutes and may even vary considerably between local jurisdictions. According to The Justice Project, the evidence the defense is entitled to receive under the law is incumbent on both the "charge itself" and the "location of the trial" ("Expanded Discovery in Criminal Cases", p.1). Since the 1970s, 46 states have built on the Brady standard and adopted open file discovery laws, which require prosecutors to disclose not only materially exculpatory evidence but most or all evidence relating to a specific case (Lieberman and Kirshner, 2019). In the state of Texas, for instance, the Michael Morton Act, passed in 2013 after the wrongful conviction of Mr. Morton, extends prosecutorial duties beyond the constitutional requirement, mandating that prosecutors disclose all evidence relevant to the case, regardless of their assessment of the evidence's materiality. The federal system, however, has not expanded disclosure requirements and maintains a closed file system.

Despite the revisions and clarifications to the Brady doctrine by the Court and the increasing number of states that have adopted open file discovery, many legal scholars and activists argue that significant holes in discovery requirements still exist and compromise the integrity of our criminal justice system. A recent so-called "epidemic of Brady violations across the land", as described by Judge Alex Kozinski, also seems to suggest that the doctrine lacks enforcement and is still veritably susceptible to subversion and misinterpretation by prosecutors, especially in the federal court system, where disclosure requirements are at the bare constitutional minimum. ${ }^{5}$ While it is difficult to provide a fixed number of Brady violations that occur per year, in recent years, various studies by major newspapers across the country have unearthed a barrage of revelations suggesting that violations are widespread in the United States. Between 1963 and 1999 the Chicago Tribune reported that 381 of 11,000 homicide convictions were reversed due to Brady violations (Gershowitz, 2019). More recently, a study by the National Registry of Exonerations found that half of all murder exonerations between 1987 and 2017 involved the suppression of exculpatory evidence at trial (“Exonerations in 2016", 2017).

Brady violations weigh a heavy burden on defendants, whose ability to establish their best defenses often depends on the case-related information they receive from prosecutors. In a country where the leading cause of wrongful convictions is Brady violations, Brady is more than just a "discovery rule". It is "a rule of fairness and minimum prosecutorial obligation." ${ }^{6}$ The suppression of a single piece of evidence has and can make the difference between a conviction and an acquittal. Upon consideration of this reality, it becomes vital that prosecutors, defense attorneys, and other legal professionals thoroughly understand the significance of Brady and the myriad contributors to the Brady problem to prevent Brady violations.

\section{Review of Literature}

The issue of Brady violations has been documented by the press and by legal scholars for decades. With my research in both federal and state disclosure regimes, I sought to understand the various forces that contribute to this problem. Several scholarly articles and cases influenced the design, scope, and hypothesis of my experiment. I learned the Brady doctrine is complex and has flaws and loopholes that make its detection and enforcement incredibly difficult and ineffective. The literature I read exposed various problems, patterns, and developments, all of which helped shape the concept and focus of my experiment.

\section{Inadvertent Brady Violations}

\footnotetext{
${ }^{4}$ See United States v. Bagley, 473 U.S. at 682.

${ }^{5}$ See United States v. Olsen, 737 F.3d 625, 626 (9th Cir. 2013) (Kozinski, C.J., dissenting).

${ }^{6}$ See United States v. Agurs, 427 U.S. 97, 107 (1976))
} 
The articles "The Challenge of Convincing Ethical Prosecutors That Their Profession Has a Brady Problem" by Professor Adam Gershowtiz, "Brady's Bunch of Flaws" by Professor Daniel Medwed, and "Prejudice-based Rights in Criminal Procedure" by Professor Justin Murray broadened my understanding of the nature of Brady violations, specifically by detailing the flaws within the Brady doctrine itself. Both Professor Gershowitz, Medwed, and Murray debunk the idea that all Brady violations are products of unethical prosecutors and discussed the overwhelming prevalence of inadvertent violations among good-willing prosecutors.

According to Professor Gershowtiz, widely circulated periodicals that expose malicious prosecutors who intentionally withhold favorable evidence to subvert the defense have created somewhat of a one-dimensional perception of Brady violations: that all prosecutors who commit Brady violations are unethical. In reality, however, "ethical prosecutors who act in good faith" can and have violated the Brady rule as well (Gershowitz, 2019, p. 314). As Professor Gershowitz and Murray describe, the constitutional Brady standard, which requires prosecutors to assess what evidence is favorable and material to guilt or punishment, is "an amorphous test that requires judgment calls in close cases" and is thus susceptible to violations, especially by newer, undertrained prosecutors who may be overburdened and lack a thorough understanding of Brady (Gershowitz, 2019, p. 307).

A defendant's fate often rests on the ability of prosecutors to impartially and objectively assess evidence collected during discovery in the early phases of a case. As Professor Murray describes, the right to obtain favorable "material" evidence, as established by Brady v. Maryland, is an "outcome-centric prejudice based right", meaning that defendants are only protected if the trial judges and prosecutors believe there is "a reasonable probability" that the outcome of the proceeding was affected (Murray, 2020, p. 278). Professor Medwed expounds on Professor Murray's idea, explaining that the prospect of inadvertent violations is greatly increased due to the "vagueness of the [disclosure] duty's doctrinal formulation", which requires prosecutors, during the pre-trial phase, to subjectively assess if a certain piece of evidence could change the result of the proceeding (Medwed, 2010, p. 1540). This vague materiality standard gives way to subconscious cognitive biases, which can creep into a prosecutor's ability to impartially analyze evidence relating to a defendant whom they have already charged with a crime.

These factors make it clear that the Brady epidemic is far more complex than dishonest prosecutors withholding evidence in bad faith. Rather, it is a multidimensional issue and thus requires prosecutors to have a multidimensional understanding of the rule as well. After reading these articles and establishing a basic understanding of various types of Brady violations, I decided I wanted my experiment to demonstrate to prosecutors the likelihood of and risks associated with inadvertent Brady violations.

\section{Officer's Practices \& Office Culture}

Not only are prosecutors required to disclose all exculpatory and material evidence within their possession and knowledge, but according to Kyles $v$. Whitley ${ }^{7}$, are also required to seek out information within the case files of experts and law enforcement and disclose what is exculpatory to the defense in their possession. Law enforcement officers handle witness interviews and therefore have important files and notes regarding witness testimony, which often contains material exculpatory and impeachment evidence, both of which are considered Brady evidence. Therefore, police officers and other relevant members of the prosecution's team must also have a thorough understanding of the prosecutorial duty. As described by Professor Berry Scheck at Benjamin N. Cardozo School of Law, the quality of the "office culture" and Brady training within a prosecutor's office greatly influences the likelihood of Brady violations (Scheck, 2010, p. 2236).

According to Professor Scheck, the most common causes of Brady violations involve administrative lapses between prosecutors and other members within the prosecutor's office. It is not uncommon for important exculpatory

\footnotetext{
${ }^{7}$ Kyles v. Whitley, 514 U.S. 419, 437-38 (1995).
} 
or impeachment testimony to never reach the prosecutor's file in the first place (Scheck, 2010). A multitude of situations may result in such a failure. For instance, an officer may simply choose not to write down certain witness testimony that he or she does "not believe...were in any way exculpatory" (Scheck, 2010, p. 2229). Furthermore, an officer may strongly suspect testimony to be Brady material but choose not to write it down. Such administrative failures are especially likely in offices with high caseloads. Unlike physical forensic evidence such as DNA, which is processed and analyzed by third-party laboratories, information collected from witness testimony is entirely limited to the interrogator's recollection and notes, increasing the risk of error and therefore, the risk of Brady violations.

Professor Scheck's commentary regarding the risk of Brady violations involving witness testimony helped me further narrow the focus of my experiment from inadvertent Brady violations to inadvertent Brady violations involving witness testimony. Seeing as the goal of my experiment is to demonstrate how simple it is for ethical prosecutors to violate Brady, incorporating witness testimony in my experimentation seemed most reasonable.

\section{Evidentiary Disclosure During Plea Bargaining}

An overwhelming ninety-seven percent of federal and state criminal cases in the last fifty years have been resolved through plea bargains ("Report: Guilty Pleas on the Rise", 2018). The number of plea bargains rose steadily through the early twenty-first century, as defendants became increasingly wary of mandatory harsh minimum sentences. Despite the overwhelming percentage of plea-bargained convictions, the Supreme Court has consistently refused to clarify whether defendants have a right to materially exculpatory evidence at the plea bargain stage. The Court first introduced the question of disclosure at plea bargaining, when it ruled in the United States v. Ruiz that defendants have no constitutional right to receive impeachment evidence during pre-trial bargains. ${ }^{8}$ Since 2002 , federal courts have interpreted the ruling differently. ${ }^{9}$ Some courts maintain that the ruling does establish a requirement to disclose materially exculpatory evidence at plea bargaining, while others do not.

As I read the articles "Entitling the Accused to Exculpatory Evidence: Why Prosecutors Should Have to Disclose During Plea Bargaining" and "Lost Opportunity: Supreme Court Declines to Resolve Circuit Split on Brady Obligations During Plea-Bargaining", I learned that lack of disclosure during the plea bargain stage can be just as prejudicial to defendants as lack of disclosure at the trial stage. According to Clarke and Casey, the impending circuit split muddles the question of pre-trial disclosure at plea bargaining and compromises defendants' right to a fair proceeding.

Before delving into Casey and Clarke's arguments, it seemed unclear to me why disclosure at the plea bargain stage would be necessary. After all, the Brady doctrine was created to protect the defendant's fifth amendment due process rights and prevent innocent people from being found guilty; in the case of a plea agreement, I thought, aren't these concerns eliminated since the defendant has a choice to admit or deny guilt? However, as Casey and Clarke explain, an overwhelming body of evidence suggests that many defendants enter plea deals, not necessarily because they are guilty, but to avoid the "exponentially higher sentences" that may result if they choose to exercise their Sixth Amendment right (Clarke, 2019, p. 69). In fact, since 1989, approximately ten percent of exonerations have involved defendants who pled guilty to crimes they did not commit (Casey, 2020, p. 89). Taking this into consideration, Casey

\footnotetext{
${ }^{8}$ See United States v. Ruiz, 536 U.S. at 633

${ }^{9}$ The ongoing federal circuit split is rooted in conflicting interpretations of the Ruiz decision. The Seventh, Ninth, and Tenth Circuits contend that the Ruiz decision does mandate disclosure of exculpatory evidence during plea bargaining while the First Circuit, Second Circuit, Fourth Circuit, and, as of recent, the Fifth Circuit Court, suggest that defendants are not entitled to exculpatory evidence during plea bargaining. The Supreme Court, in 2018, denied certiorari of Alvarez v. City of Brownsville, which would have been an opportunity for the Court to resolve the circuit split and clarify the meaning of Ruiz. See generally "Lost Opportunity: Supreme Court Denies to Resolve Circuit Split on Brady Obligations".
} 
and Clarke argue that knowledge of exculpatory evidence could be crucial to a defendant's decision to enter a guilty plea.

After reading Casey and Clarke's arguments, I began to consider the factors defendants consider when deciding whether or not to accept a plea deal and wondered how much weight exculpatory evidence would have on a defendant's decision. To test this question, I decided to incorporate the plea bargain question into my experiment.

\section{Methods}

The literature I reviewed regarding evidentiary disclosure prompted me to focus my experiment around two central questions: (1) how can the exclusion of a single piece of seemingly unimportant witness testimony from a trial impact a jury's opinion of the defendant's culpability? (2) how can the presence or absence of Brady material influence a defendant's decision to accept a plea deal? As previously stated, my goal with this experiment was to demonstrate how a seemingly immaterial piece of evidence could have severe consequences for a defendant later in their case. The research I conducted had made clear that witness testimony, which is obtained by police officers, and for which there is usually no formal system of information collection aside from an officer's independent notes, is among the most common types of evidence involved in Brady violations. Unlike physical evidence such as a weapon, DNA, or footprints, whose materiality and relevance may be more immediately apparent to police officers and prosecutors, witness impeachment testimony is not only easier for prosecutors to suppress, but to deem unimportant as well.

State v. Mulligan, the case I created, involves the stabbing of a 28-year-old woman, Harper Grace, whose body was found in a bag and buried in a forested area behind a fictional restaurant by the name of Andy's Steakhouse. The individual on trial in this case, Jack Mulligan, is an employee at the Steakhouse and a close friend of the deceased's boyfriend. Two versions of the case, Version A and Version B, were created. Version A included all of the evidence collected during discovery whereas Version B of the case excluded a piece of witness testimony, deemed Brady material by my subjective assessment. Whether or not the State of Midlands enforces an open-file discovery policy is irrelevant to the experiment. It is stipulated that evidence was suppressed regardless of the existence of an open file policy or other statutory disclosure obligations. It is also stipulated that there were no objections to the facts listed in the presentation and all facts presented are admissible in court.

To best reflect the nature of a jury, participants possessed little to no technical legal knowledge. The fortyfour volunteers were split up into two groups, each consisting of twenty-two individuals. Depending on which group they were assigned to, every participant was sent a slideshow presentation via email of either Version A or Version B of the case. They were given between two weeks and three days to independently review the facts and submit the questionnaire on their own time. Each fact was listed in the form of a bulleted sentence. Participants were not told that there is more than one version of the case, and after reviewing the facts were asked to acknowledge that no outside assistance was solicited during the course of the activity. Participants were also asked to acknowledge that they read the facts of the case "thoroughly and properly".

\section{The questionnaire included the following questions:}

You are a member of the jury in this trial. What is your verdict based on the facts you were presented? Is the defendant Jack Mulligan guilty or not guilty?

Participants were provided the following definition of "reasonable doubt":

"A doubt based upon reason and common-sense after careful and impartial consideration of all the evidence in the case. Proof beyond a reasonable doubt, therefore, is proof of such a convincing character that you would be willing to rely and act upon it without hesitation in making the most important decisions of your own affairs." 
Putting all legal definitions aside, from a common sense, everyday human perspective, do you think Jack killed Harper?

"You are the Defendant's (Jack Mulligan's) attorney. The maximum penalty your client faces if convicted is 99 years or life, but the prosecutor has offered your client a plea deal that would reduce the sentence to 15 years in prison instead. Will you advise your client to accept the plea deal or would you rather go to trial?"

I predicted that a majority of participants in Group A would deny the plea deal and deliver a verdict of "not guilty". As for Group B, I predicted that a majority would accept the plea deal and deliver a verdict of "guilty". Approximately three weeks after sending out the questionnaire, all forty-four participants had reviewed the facts of the case and completed the questionnaire.

\section{Results}

\section{Overview of Group A Responses}

Participants in Group A reviewed the complete version of the case, including the piece of evidence I deemed materially exculpatory. I hypothesized that the majority of the participants in this group would deliver a verdict of not guilty and advise the defendant to deny the plea deal. Despite the presence of the piece of "exculpatory" evidence, the answers to Question one were fairly evenly split, with $54.5 \%$ delivering a verdict of not guilty and an overwhelming $45.5 \%$ of participants delivering a verdict of guilty (Figure 1).

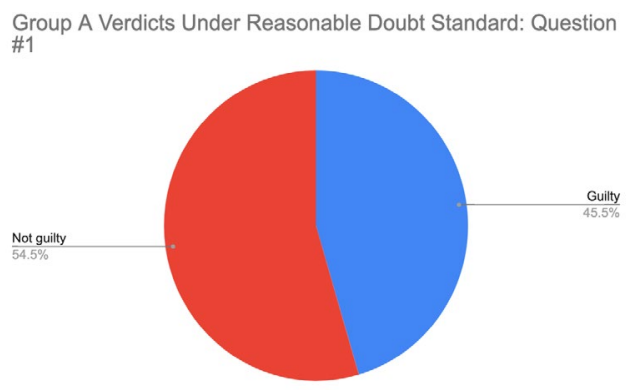

Figure 1

The answers to Question two have a similar split, however, the numbers are flipped (Figure 2). While 54.5\% of those in Group A believed Jack Mulligan to be "not guilty" of first-degree murder under the reasonable doubt standard, when questioned about Mulligan's culpability from a common-sense perspective, only $45.5 \%$ of respondents believed the defendant to be innocent. Although most who delivered a verdict of not guilty answered that they "do not think Jack killed Harper", 33.3\% do think Jack caused Harper's death (Figure 3). 


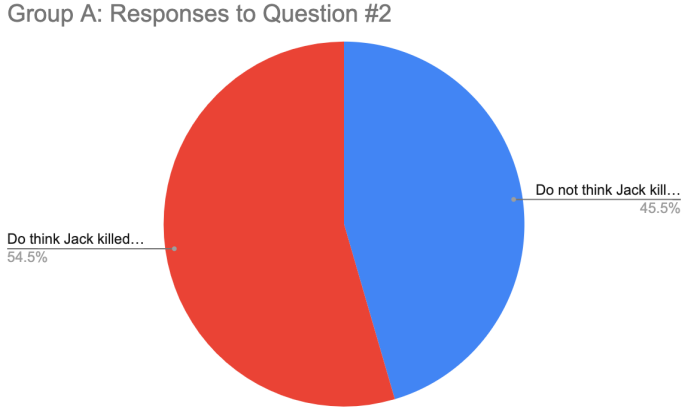

Figure

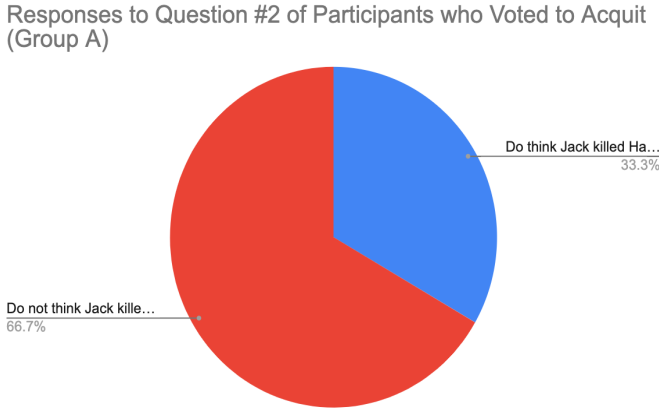

2

Figure 3

Contrary to what I had hypothesized would occur, the majority of participants advised the client to accept the plea deal and avoid trying the case (Figure 4). Juxtaposing Group A's responses to Question three with their responses to Question one provides insight into the reasoning behind

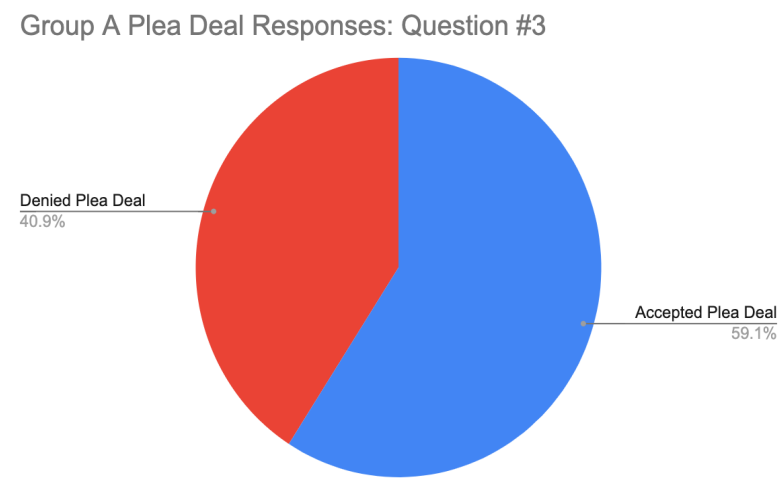

Figure 4

the participants' answers. Logically, the majority of those who advised accepting the plea deal believed Mulligan was guilty beyond a reasonable doubt while only $30.8 \%$ of those who accepted the plea deal believed the defendant was not guilty (Figure 5). Likewise, the majority of those who advised denying the plea deal delivered a verdict of "not guilty" while only $11.1 \%$ delivered a guilty verdict (Figure 6). There are many reasons other than the nature of the evidence that may 


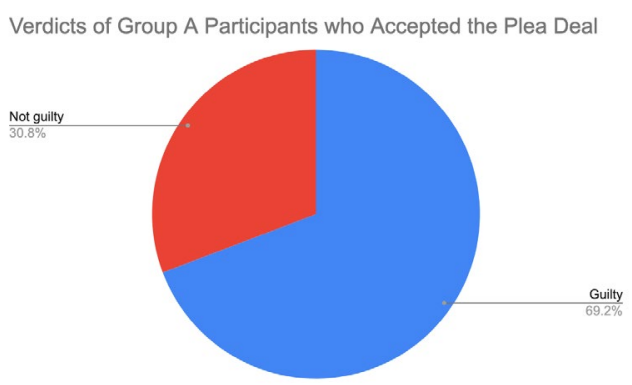

Figure 5

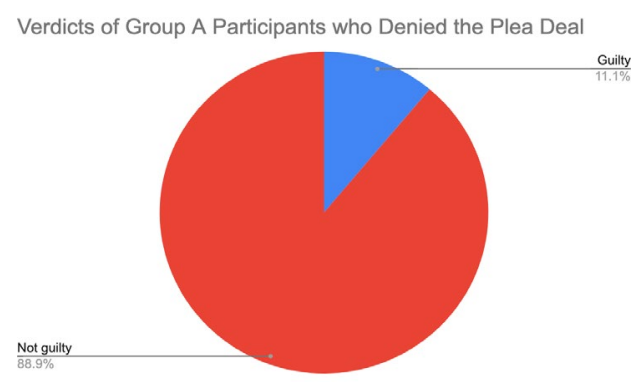

Figure 6

influence an attorney's advice to his or her client regarding a plea deal. The personal and financial situation of the accused, his or her criminal history, and internal willingness to take the risk of going to trial all factor into a defense attorney's advice. In this experiment, however, participants answered the questions based only on the facts of the case and the accompanying details about the proposed sentence reduction.

\section{Overview of Group B Responses}

Participants in Group B reviewed Version B of the case, which omits a single piece of Brady evidence. I hypothesized that the omission of this piece of evidence would (1) yield an overwhelming verdict of guilty from respondents and (2) lead respondents to advise their client to accept the plea deal. However, the results strayed significantly from my expectations. Group B's responses to Question one were identical to Group A's responses, in that $54.5 \%$ of respondents delivered a verdict of "not guilty" (Figure 7). When asked to put all legal definitions aside, however, 59.1\% of Group B respondents did not believe the defendant had killed Harper Smith (Figure 8).

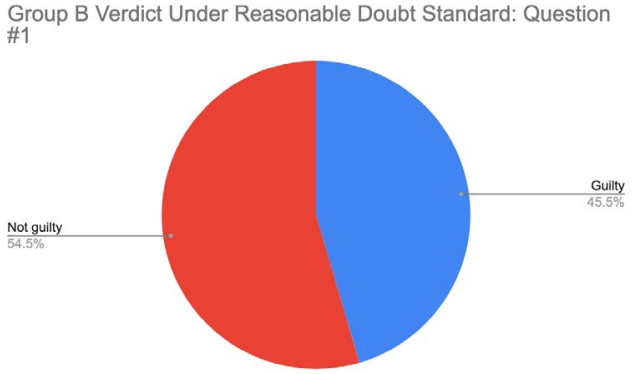

Figure 7

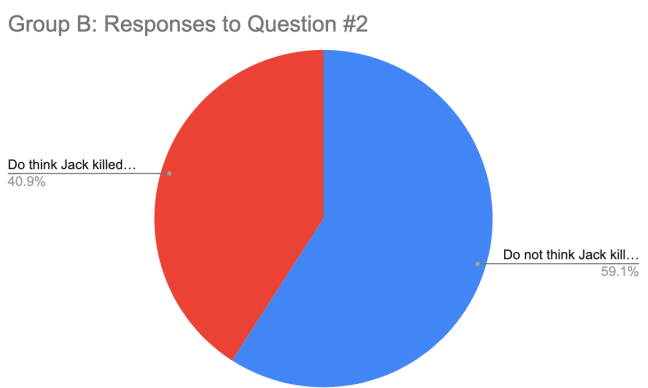

Figure 8

The exclusion of the materially exculpatory evidence, which I expected would paint a clear picture of guilt, seemed to not have had the intended effect on participants' judgment, suggesting that the impact of the excluded evidence on the defendant's verdict was largely negligible. Group B's responses to Question three, unlike Group A's, were evenly distributed between those who advised denying the plea deal and those who advised accepting it (Figure 9). As in Group A, the majority of 


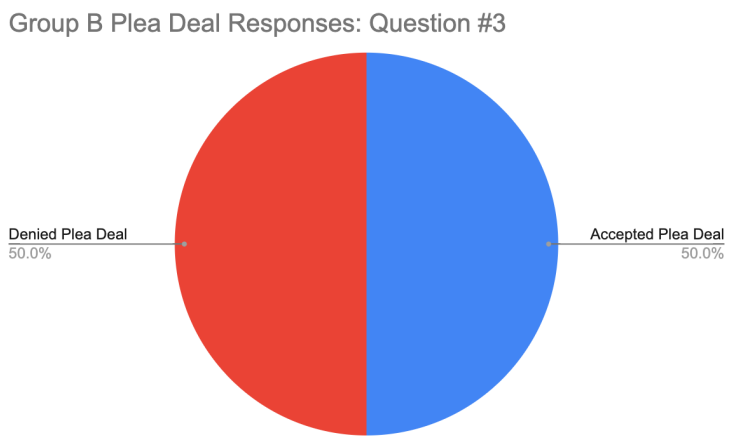

Figure 9

those who advised accepting the plea deal delivered a verdict of guilty (Figure 10). Likewise, the majority of those who advised denying the plea deal delivered a verdict of not guilty (Figure 11). These comparisons suggest that, in the absence of other significant contributing factors, there is a correlation between the impression of guilt or innocence and the decision to accept or deny the plea deal.

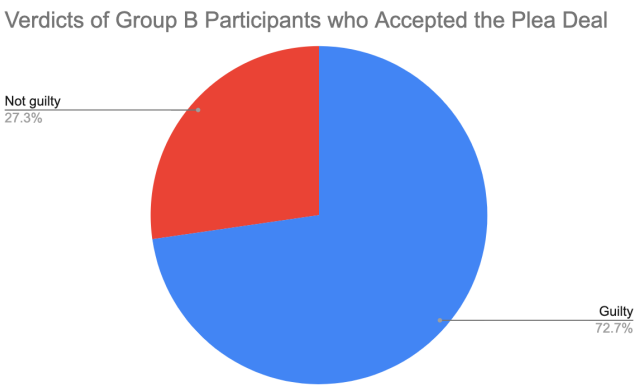

Figure 10

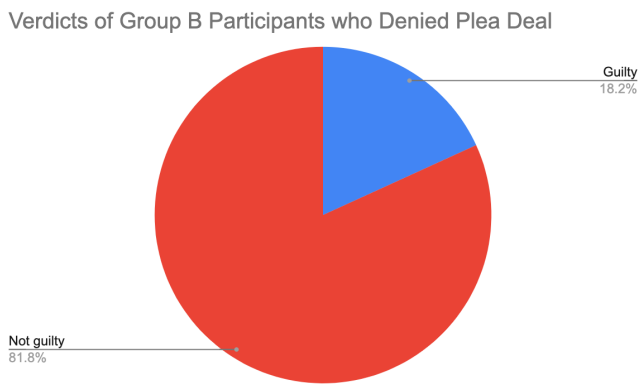

Figure 11

\section{Discussion}

The responses from Group A and Group A suggest that the impact of the evidence had a negligible effect on participants' responses to the plea bargain question. Variances between Group A's and Group B's responses are far too minute to suggest that the dependent variable had any weight in the respondents' judgment. Regardless of this upset, this experiment has various implications for the significance and complexity of the disclosure duty.

First and foremost, both Group A and Group B's responses to Question three suggest that an attorney's assessment of the evidence disclosed has significant weight on the type of advice that he or she may offer to a client. Secondly, the results, when analyzed in conjunction with the methodology, demonstrate that in the absence of open file discovery laws, subconscious biases can impact prosecutors' ability to make objective assessments of evidence collected in discovery. We can also use the results of the experiment to assess and make various predictions about the procedural future and outcome of the case State v. Mulligan. 
Firstly, individual responses to Question three in both Group A and Group B reveal that the nature of the plea bargaining advice offered is directly correlated with individual responses to Question one, which supports the argument that defendants must be able to holistically review all of the evidence against them to make an informed plea negotiation. Failure to disclose evidence promptly compromises the defendant's right to a proper and fair proceeding by depriving them of crucial information necessary to adequately assess the risks of trial and make an informed decision. As discussed previously, the failure of the Supreme Court to clarify the question of Brady disclosure during plea bargaining harms defendants and undermines the integrity of our adversarial system of justice by giving one side a leg up over the other.

Secondly, the unexpected responses from respondents also show that the definition of "materially exculpatory" evidence is entirely subjective and is therefore an unsustainable standard for pre-trial evidentiary disclosure. The results demonstrate that the objective value of the evidence is even more blurred when taking into consideration potential prosecutorial biases. When designing this experiment, my role was akin to that of a prosecutor, in that I exercised discretion and determined what pieces of evidence would be exculpatory, inculpatory, or red herrings. I strategically crafted both versions of the case in a manner that I believed would yield a specific verdict. By approaching the experimental design with a preconceived notion of guilt or innocence, my ability to objectively assess the materiality of other seemingly irrelevant facts was likely distorted and thus produced unexpected responses, specifically from participants in Group B, most of whom voted to acquit the defendant, even in the absence of the excluded evidence. Confident that the design of Version B communicated a clear picture of guilt, I likely overestimated the inculpatory effect of the evidence and underestimated the exculpatory effect of the "red herrings". The disparity between my assessment of the evidence and the results of the experiment demonstrates that there are severe risks associated with subjecting prosecutors to the constitutional Brady standard, such as the potential for biases to cloud prosecutors' objective assessment of the evidence. The simpler, safer, and more equitable course of action for prosecutors that avoids having to subjectively assess the evidence is to simply practice open file discovery.

Using the results of the experiment, we can make predictions about the procedural future of the case. Making these predictions can allow us to understand how prosecutorial misconduct, particularly suppression of evidence, can ultimately prolong the litigation process and make the route to justice more cumbersome for all parties involved. Responses from both Group A and Group B demonstrated a close split between those who voted guilty and not guilty. In both trials, $45.5 \%$ of participants voted guilty and $54.5 \%$ of participants voted not guilty. Deeming the two-vote disparity negligible, the trials can be considered undecided. Assuming a jury deliberation period occurs and resolves the split in both trials, the defendant, if a verdict of guilty is delivered, may address any uncovered Brady violations in post-trial motions. For instance, the defense attorney may motion for a new trial or motion to vacate the conviction or sentence. In most cases, however, Brady violations are rarely uncovered by the defense (Dewar, p. 1455). While different states have different statutes that govern the handling of post-trial motions, under the constitution, the defendant must prove that the suppressed evidence meets the Bagley standard, according to which there must be a "reasonable probability that its disclosure would have produced a different result." Depending on the trial court's opinion on the matter, the defendant may be granted or denied a retrial. If the evidence is found to be Brady evidence, the court may also impose sanctions on the prosecution. However, in most cases, prosecutors face modest punishment for their actions, as the government is usually reluctant to impose harsh punishments on prosecutors. If the motion is denied, the defendant may appeal the case to a higher court to overturn the trial court's denial.

Post-trial procedure is an entire subject of its own, the complexities of which should be further explored in a separate study; however, this brief overview highlights the procedural struggles involved with Brady violations, which ultimately complicate the judicial process for both sides and the Court. Since the case was highly inconclusive according to the experimental data, it is highly plausible that if the defendant Jack Mulligan were to be found guilty, the court may deny the motion for retrial on the basis that a Brady violation never occurred. In a case as close as State $v$ Mulligan, the line between material and immaterial evidence is blurred beyond objectivity, placing the fate of the defendant in the hands of entirely subjective assessments. 


\section{Limitations}

There are several limitations to this experiment that are worth considering when analyzing the implications of the experiment. First and foremost, it is important to understand that every case is different, and therefore the suppression of evidence in one case may have a substantially different impact on the proceedings than the suppression of evidence in another case. The results of this experiment are therefore by no means representative of the effects of Brady violations in all criminal cases. A multitude of factors is taken into consideration when plea bargaining, and depending on the nature of the case and the quality of the accused's legal defense, Brady violations may be handled differently in different cases.

One limitation of the experiment has to do with how the facts of the case and questions were presented to the participants. The facts of the case were presented in a relatively uncontrolled environment, making it possible that external and unwanted forces impacted participants' assessment of the facts and responses to the questionnaire. Other than the series of acknowledgements participants were asked to make there was no additional oversight over the participants as they individually reviewed the facts of the case and answered the questions. Although participants were asked to confirm that they thoroughly reviewed and understood the materials in the presentation in the Google Form and were also made aware of the importance of their responses, it is impossible to know whether or not every participant paid sufficient attention when reviewing the facts.

It is also important to note that there were minor errors during the data collection process that may impact the validity of the results. Shortly after the participants in both groups received the facts of the case, it was brought to my attention that there was an error on slide number eight of the presentation, which displayed the text message conversation between the defendant and his friend (Figure 12). One of the names displayed in the defendant's message to his friend was inaccurate. I immediately corrected the error and informed all participants that had submitted answers to review the facts again and submit another response if their assessment had changed (Figure 13). On the questionnaire form, I added a statement that asked participants to acknowledge that they had

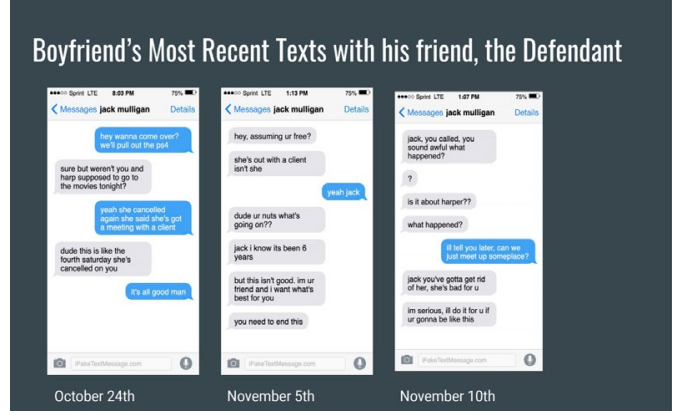

Figure 12

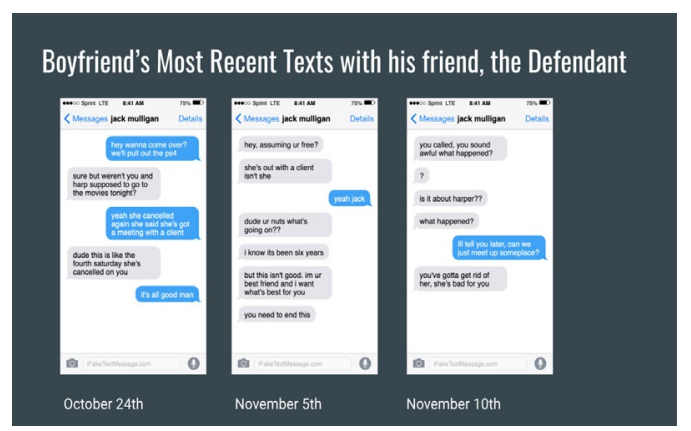

Figure 13

received and read the email update with the error corrected. This error may have resulted in confusion among participants who reviewed the erroneous version of the facts. However, considering the nature of the error was not substantially prejudicial to the accuracy of the facts, any confusion should have most likely been addressed with the corrected slides.

There are various ways in which this experiment can be improved to provide a more thorough analysis of the disclosure duty. Firstly, to minimize error and ensure that no external factors are impacting participants' assessment of the evidence, the facts of the case would be presented in a live setting with all participants present at the same time. This adjustment would not only prevent lapses in understanding and communication but would also more accurately reflect the nature of our judicial process and make the data collection process more expedient. With participants reviewing the case at the same time in the same environment, it would also be easier to retain participants' attention and 
ensure that every participant is paying attention. Furthermore, instead of having an independent deliberation process, adjusting the experiment to include a period of jury deliberation would also provide a more accurate picture of the nature of criminal proceedings.

\section{Conclusion and Implications}

Two key conclusions were drawn based on my semester of research and experimentation on the Brady Rule. Firstly, the Brady rule is a highly complex, multifaceted, and subjective standard that is prone to both inadvertent and malicious violations. Secondly, the results of the experiment show that the lack of a disclosure requirement during plea bargaining can be highly prejudicial to the defense, as many defendants plead guilty, even if they are truly innocent, to avoid significantly higher sentences imposed by mandatory minimums. Despite the promises of fairness and due process made by the Supreme Court in the 1963 ruling, the doctrine alone does not fulfill its promises.

Legal scholars and reformers have proposed various reforms to address the flaws of the disclosure doctrine. These reforms involve legislatively expanding the disclosure duty and increasing prosecutorial accountability to deter future violations. While many states have adopted an open file discovery policy, the federal system still maintains a closed file policy, which a multitude of scholars argues against. Regardless of the existence of open file disclosure requirements, the Supreme Court agrees with scholars who urge prosecutors to err on the side of disclosure when uncertain about the materiality of the evidence. While some scholars argue for increased legislative protections and judicial clarifications, scholars like Cynthia E. Jones argue that trial courts should increase oversight over prosecutors during the discovery process. ${ }^{10}$ Preventative policies and procedures can and should also be established by prosecutors within their offices to minimize the likelihood of inadvertent Brady violations. This includes ensuring that police officers, prosecutors, and other members of the prosecution team have received sufficient training on Brady and cognitive bias.

As Brady is a widely discussed legal issue, scholars, attorneys, and other legal professionals have recommended a multitude of other reforms to improve the pre-trial disclosure process. I believe that addressing the Brady problem begins with thoroughly understanding it. Prosecutors, defense attorneys, and other stakeholders must understand that Brady violations have serious consequences. Although accurate quantitative data on the scope of Brady violations remains elusive, it has been widely agreed by scholars and judges alike that Brady violations are commonplace in our justice system and hurt indigent defendants with poor defense the most. As long as Brady violations remain commonplace, the cracks in our justice system will continue to compromise the integrity of our judicial processes and put innocent men and women in prison.

\section{Acknowledgments}

Thank you first and foremost to my advisor Mr. Ryne Sandel, who helped me turn my interest in pretrial discovery, indigent defense, and criminal justice reform into a focused, fun, and immersive research project that has forced me to challenge myself and explore my legal interests. I also want to thank the various legal professionals, professors, and attorneys who took the time to virtually meet with me and answer my questions about criminal law.

Thank you to Ms. Penney, my Independent Study and Mentorship teacher, who encouraged me to pursue my passions and offered constructive feedback on my assignments and speeches. Finally, thank you to the Frisco Independent School District for creating a program that allows students like me to explore their passions, think independently, forge professional relationships, and build lifelong skills for success.

\footnotetext{
${ }^{10}$ See generally "Here Comes the Judge: A Model for Judicial Oversight and Regulation of the Brady Disclosure Duty" by Cynthia E. Jones
} 


\section{References}

Casey, Cameron (2020). Lost Opportunity: Supreme Court Declines to Resolve Circuit Split on Brady Obligations During Plea-Bargaining, 61 B.C.L. Rev. E.Supp. II.-73. https://lawdigitalcommons.bc.edu/bclr/vol61/iss9/11/

Clarke, Emily (2019). "Entitling the Accused to Exculpatory Evidence: Why Prosecutors Should Have to Disclose During Plea Bargaining” American Criminal Law Review, vol. 56, 2019. https://www.law.georgetown.edu/americancriminal-law-review/aclr-online/volume-56/entitling-the-accused-to-exculpatory-evidence-why-prosecutors-shouldhave-to-disclose-during-plea-bargaining/

Dewar, Elizabeth Napier (2006). A Fair Trial Remedy for Brady Violations, 115 Yale L.J. https://digitalcommons.law.yale.edu/ylj/vol115/iss6/5

Gershowitz, Adam M. (2019). "The Challenge of Convincing Ethical Prosecutors That Their Profession Has a Brady Problem". 16 Ohio State Journal of Criminal Law, 307-324. https://scholarship.law.wm.edu/facpubs/1922

Innocence Project. (2018, August). "Report: Guilty Pleas on the Rise, Criminal Trials on the Decline." Innocence Project. https://innocenceproject.org/guilty-pleas-on-the-rise-criminal-trials-on-the-decline/.

Jones, Cynthia E. (2018) "Here Comes the Judge: A Model for Judicial Oversight and Regulation of the Brady Disclosure Duty," Hofstra Law Review: Vol. 46: Iss. 1, Article 8. https://scholarlycommons.law.hofstra.edu/hlr/vol46/iss $1 / 8$

Lieberman, Donna, \& Isabelle Kirshner (2019). "Take off the Blindfold: Reform NY Discovery Law (Commentary)." New York Civil Liberties Union. www.nyclu.org/en/publications/take-blindfold-reform-ny-discovery-law-commentary\#: :text=In\%20New\%20York\%2C\%20prosecutors\%20have,very\%20day $\% 20 \mathrm{a} \% 20$ trial $\% 20$ starts.

Medwed, Daniel S. (2010). Brady's Bunch of Flaws. Washington and Lee Law Review, Vol. 67, p. 1533. Available at SSRN: https://ssrn.com/abstract=1723426

Murray, Justin (2020). Prejudice-Based Rights in Criminal Procedure, 168 U. Pa. L. Rev. 277. Available at: https://scholarship.law.upenn.edu/penn_law_review/vol168/iss2/1

New York Civil Liberties Union. (2019, February). “Discovery in the Dark: New York's Secret Evidence Rules.” New York Civil Liberties Union. https://nyclu.org/sites/default/files/discoveryinthedark 2019.pdf

Scheck, Barry (2010). Professional and Conviction Integrity Programs: Why We Need Them, Why They Will Work, and Models for Creating Them, Cardozo Law Review, Vol. 31, No. 6, Cardozo Legal Studies Research Paper No. 312. Available at SSRN: https://ssrn.com/abstract $=1684690$

The National Registry of Exonerations. (2017, March). "Exonerations in 2016”. The University of Michigan Law School. https://www.law.umich.edu/special/exoneration/documents/exonerations in 2016.pdf 